\title{
Case report of acquired hemophagocytic lymphohistiocytosis associated with progression of monoclonal gammopathy of unknown significance (MGUS)
}

\author{
Li Liu, Lydia C Contis, Octavia M. Peck Palmer* \\ University of Pittsburgh School of Medicine, and University of Pittsburgh Medical Center, United States
}

Received: February 12, 2018

DOI: $10.5430 /$ crcp.v5n1p19
Accepted: April 10, 2018

Online Published: June 21, 2018

\begin{abstract}
Background: Acquired hemophagocytic lymphohistiocytosis (HLH) is an aggressive hyperinflammatory syndrome. Without prompt diagnosis and proper treatment, it can be life-threatening. HLH is commonly present in the setting of other autoimmune disorders, infection, organ transplantation, and malignancy. However, to our knowledge, HLH associated with monoclonal gammopathy of undetermined significance (MGUS) has not been reported.

Case presentation: A 67-year-old woman with an extensive history of MGUS and renal transplant presented with progressive fatigue, weight loss, intermittent fevers, splenomegaly, and pancytopenia. Serum protein electrophoresis with immunofixation identified a new monoclonal protein IgG lambda and a rapidly increasing pre-existing free kappa light chain. A bone marrow biopsy revealed focal clusters of kappa restricted plasma cells which comprised less than $10 \%$ of marrow cellularity. Skeletal survey was negative for osteolytic lesions. She was also free of any end-organ damage. Histological examination showed a prominent increase in histiocytes and macrophages, many of which show erythrophagocytosis and lymphophagocytosis. Together with her clinical presentation along with a hyperferritinemia, a diagnosis of HLH was confirmed utilizing the criteria of the Histiocyte Society. The patient underwent a splenectomy. Prompt treatment with etoposide and high dose dexamethasone eventually stabilized the patient and resulted in a full recovery, which coincided with the disappearance of the serum monoclonal IgG lambda.

Conclusions: This report reveals a novel association of HLH with the progression of MGUS. Familiarity with this syndrome and its association with other conditions is indicated to ensure prompt diagnosis and appropriate patient treatment.
\end{abstract}

Key Words: Hemophagocytic lymphohistiocytosis (HLH), Monoclonal gammopathy of undetermined significance (MGUS), Transplant

\section{INTRODUCTION}

Hemophagocytic lymphohistiocytosis (HLH) is a rare but life-threatening condition characterized by an overstimulated, but inefficient immune response resulting in multisystem in- flammation. HLH occurs in two forms: the familial form and the acquired form. Familial HLH results from autosomal recessive mutations and is primarily found in children, while the acquired form of HLH can occur in any age

\footnotetext{
*Correspondence: Octavia M. Peck Palmer; Email: ogp2@pitt.edu; Address: University of Pittsburgh School of Medicine, and University of Pittsburgh Medical Center, United States.
} 
group. $^{[1-4]}$ It is a syndrome associated with a variety of underlying conditions including severe sepsis, autoimmune disorders, malignancy, and immune suppression/organ transplantation. ${ }^{[5-8]}$ Without appropriate treatment, the uncontrolled inflammation contributes to significant morbidity and mortality. Therefore, familiarity with the clinical features of HLH and the diagnostic criteria is imperative for establishing a prompt diagnosis. Diagnosis of HLH incorporates several patient factors that include: clinical manifestation, histology, and laboratory test results. The guidelines published by the Histiocyte Society indicate that five of eight criteria must be fulfilled to diagnose $\mathrm{HLH} .{ }^{[9]}$ These include: fever; splenomegaly; cytopenia affecting a least two lineage $(\mathrm{Hb}<$ $90 \mathrm{~g} / \mathrm{L}$, Plt $<100 \times 10^{9} / \mathrm{L}$, neutrophils $<1.0 \times 10^{9} / \mathrm{L}$ ) , hypertriglyceridemia ( $>3.0 \mathrm{mmol} / \mathrm{L}$ ) and/or hypofibrinogenemia $(<1.5 \mathrm{~g} / \mathrm{L})$; hemophagocytosis in bone marrow, spleen or lymph nodes; hyperferritinemia ( $>500 \mu \mathrm{g} / \mathrm{L}$ ); low or absent NK-cell activity; and an elevated level of soluble interleukin 2 receptor (sIL-2r, sCD25) $>2,400 \mathrm{U} / \mathrm{ml}$.

The most frequent form of acquired HLH is infectionassociated HLH (predominantly EBV-associated HLH), followed by lymphoma-associated HLH. ${ }^{[10]}$ However, HLH associated with MGUS, to our knowledge, has not been reported. Here we present a case of HLH in a patient with a history of MGUS and renal transplant. The development and subsidence of HLH were coincident with the emerging and disappearance of a new serum monoclonal antibody.

\section{Case presentation}

The patient is a 67-year-old Caucasian woman with a history of renal transplant three years before she presented for end- stage renal disease secondary to chronic obstruction from nephrolithiasis and currently taking tacrolimus for immunosuppression. The urine protein electrophoresis exhibited a monoclonal kappa light chain spike. However, the serum protein electrophoresis was unremarkable. Her serum albumin was $2.7 \mathrm{~g} / \mathrm{dl}$. A bone marrow biopsy showed a low percentage $(0.8 \%)$ of cytoplasmic kappa-restricted, phenotypically abnormal (CD19-, CD138+, CD56+) plasma cells by flow cytometry, but did not meet the criteria for plasma cell myeloma (PCM). Skeletal survey and fat pad biopsy for amyloid were both negative. She was diagnosed with MGUS.

The patient's condition had been stable for three years postrenal transplant until she started to experience progressive fatigue, weight loss, intermittent fevers up to $101^{\circ} \mathrm{F}$, worsening neutropenia progressing to pancytopenia, night sweats, and pruritus. Her symptoms persisted so she started to be extensively evaluated. Serum protein electrophoresis with immunofixation identified a biclonal gammopathy with a new emerging IgG lambda ( $0.33 \mathrm{~g} / \mathrm{dl})$ and free kappa light chain (see Figure 1A). Serial serum free light chain measurements showed a rapidly rising kappa to lambda ratio (see Table 1). Bone marrow biopsy showed focal small clusters of kappa restrictive plasma cells that comprised approximately $10 \%$ of marrow cellularity. The aspirate smear also showed an increased percentage of plasma cells. Whole-body CT scan was negative except for the enlarged spleen. She exhibited no lytic skeleton lesions or evidence of amyloid was found. In summary, although the patient's serum monoclonal protein profile was progressing, PCM was not identified. The etiology of her pancytopenia was not determined.

A. At hospital presentation
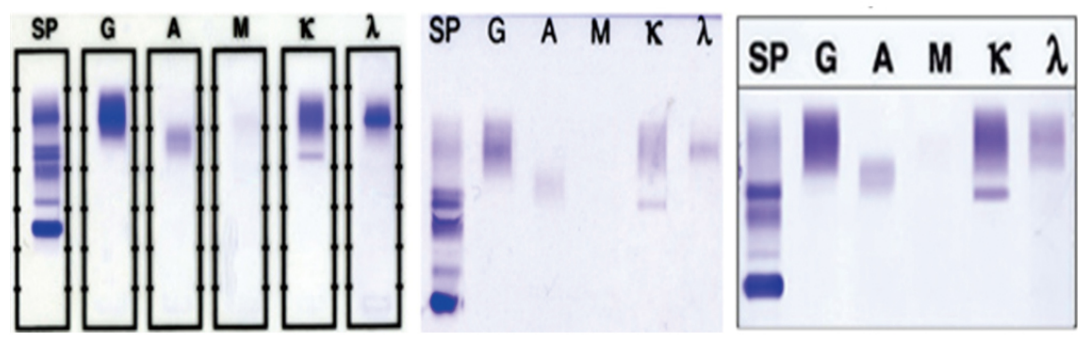

Figure 1. Patient serum protein electrophoresis with immunofixation. As shown in Figure 1, the serum protein electrophoresis with immunofixation exhibited at hospital presentation (A) a biclonal gammopathy with a new emerging IgG lambda and free kappa light chain. However, at hospital discharge (B) the monoclonal IgG lambda was significantly decreased, and the free kappa chain was still present. One year post-hospital discharge (C) the monoclonal IgG lambda was absent.

The patient's condition deteriorated despite treatment with filgrastim and blood transfusions for her pancytopenia. She has had a 30-lb weight loss and intermittent fevers. Her blood counts ranged: WBC 0.2-0.5 × 10 ${ }^{9} / \mathrm{L}, \mathrm{RBC} 2.5-3.1 \times$ 1,012/L, Hb 7.5-9.5 g/dl, Hct 22-26\%, Plt 140-160 ×10 $/ \mathrm{L}$. Other significant laboratory results included an increasing 
serum ferritin ranging from $550 \mathrm{ng} / \mathrm{ml}$ to $>1,500 \mathrm{ng} / \mathrm{ml}$ (reference range: $10-282 \mathrm{ng} / \mathrm{ml}$ ), hypofibrinogenemia (89 $\mathrm{mg} / \mathrm{dL}$, reference range: $205-508 \mathrm{mg} / \mathrm{dL}$ ) and hypoalbuminemia (1.3 g/dL, reference range: $3.4-5.0 \mathrm{~g} / \mathrm{dL})$. Blood and urine cultures and virology profiles did not identify an infectious origin for her condition. She underwent a splenectomy out of concern that her splenomegaly was due to post-transplant lymphoproliferative disorder. Histologic sections, together with immunohistochemical stains of the spleen, demonstrated a prominent increase in histiocytes and macrophages, many of which showed erythrophagocytosis and lymphophagocytosis, consistent with hemophagocytic lymphohistiocytosis. The patient fulfilled six of eight HLH diagnostic criteria (see Table 2$)^{[11,12]}$ and was diagnosed with hemophagocytic lymphohistiocytosis.

Table 1. Patient serum free light chain kappa to lambda ratio results

\begin{tabular}{lllllll}
\hline & $\begin{array}{l}\text { Pre-renal } \\
\text { transplant }\end{array}$ & $\begin{array}{l}\text { Post-renal } \\
\text { transplant }\end{array}$ & $\begin{array}{l}\text { Initial hospital } \\
\text { admission }\end{array}$ & $\begin{array}{l}\text { 1-month } \\
\text { post }\end{array}$ & $\begin{array}{l}\text { 2-months } \\
\text { post }\end{array}$ & $\begin{array}{l}\text { 1-year } \\
\text { post }\end{array}$ \\
\hline$\kappa / \lambda$ Ratio & 18.3 & 21.0 & 45.4 & 63.9 & 132.6 & 74.3 \\
\hline
\end{tabular}

Table 2. Diagnostic Criteria for Hemophagocytic Lymphohistiocytosis ${ }^{[1]}$

\begin{tabular}{|c|c|}
\hline & Patient's Values and clinical status (Reference Range) \\
\hline \multicolumn{2}{|l|}{ Six of the Eight criteria listed below are fulfilled: } \\
\hline Ferritin $\geq 500 \mathrm{ng} / \mathrm{ml}$ & $>1,500 \quad(10-282 \mathrm{ng} / \mathrm{ml})$ \\
\hline Fever & Present (Absent) \\
\hline Splenomegaly & Present (Absent) \\
\hline \multicolumn{2}{|l|}{ Cytopenias } \\
\hline Hemoglobin $<9$ g/dl & $7.5 \quad(12.9-16.9 \mathrm{~g} / \mathrm{dl})$ \\
\hline Platelets $<100 \times 10^{9} / \mathrm{L}$ & $140 \times 10^{9}\left(156 \times 10^{9}-369 \times 10^{9} / \mathrm{L}\right)$ \\
\hline Neutrophils $<1 \times 10^{9} / \mathrm{L}$ & $0.05 \times 10^{9}\left(2.24 \times 10^{9}-7.68 \times 10^{9} / \mathrm{L}\right)$ \\
\hline Hypertriglyceridemia $\geq 265 \mathrm{mg} / \mathrm{dl}$ & $184 \quad(44-150 \mathrm{mg} / \mathrm{dl})$ \\
\hline Hypofibrinogenemia & $(205-508 \mathrm{mg} / \mathrm{dl})$ \\
\hline Hemophagocytosis in bone marrow, spleen, or lymph nodes & Present (Absent) \\
\hline Low or absent NK-cell activity & Result not available \\
\hline Soluble CD25 $\geq 2,400 \mathrm{U} / \mathrm{ml}$ & Result not available \\
\hline
\end{tabular}

A chemotherapy regimen, adapted from the literature ${ }^{[13]}$ with modification, was instituted. The regimen consisted of twiceweekly (on day 1 and 4) doses of etoposide $\left(75 \mathrm{mg} / \mathrm{m}^{2}\right.$ ) and daily doses of dexamethasone $\left(10 \mathrm{mg} / \mathrm{m}^{2}\right)$. After a prolonged hospital stay of over four months, she was stabilized and discharged. Interestingly, a repeat serum electrophoresis with immunofixation before discharge showed a reduced monoclonal IgG lambda, although the free kappa chain was still present (see Figure 1B). A year after her hospital discharge, she had fully recovered and had blood counts within the normal range. The monoclonal IgG lambda disappeared (see Figure 1C), although her serum free light chain kappa to lambda ratio remained elevated (see Table 1).

\section{Discussion}

Reports have described the association of HLH with solid organ transplant (liver, heart, and lung transplant) in patients receiving immunosuppressive therapy. A comprehensive literature review from 2011 found 69 cases of HLH in solid organ transplant recipients, among which 60 cases associated with renal transplant. ${ }^{[14]}$ HLH development ranged from 2 weeks to 18 years after renal transplant, with the majority occurring from several months to one year. In our case, the onset of HLH was three years after renal transplant. Among these 60 renal transplant cases, most had an underlying infectious etiology (EBV, CMV, HHV-6, HHV8, HCV, HSV, histoplasmosis, toxoplasmosis, babesiosis, tuberculosis, and leishmaniasis) and others an underlying malignancy (T-cell lymphoma, angiosarcoma, and Kaposi sarcoma). Only five cases had no known etiology. We did not identify any causative infectious agents in our present case. Although the patient's EBV IgG titer was positive, her low EBV DNA copy and negative EBV IgM did not support recent EBV reactivation. Notably, the patient had a concurrent progression of MGUS during the same period of her HLH development, with the emergence of a new serum monoclonal protein and an increase in her pre-existing free kappa chain. 
The association of acquired HLH and hematological malignancy is rare. To our knowledge, HLH association with MGUS has not been reported. We found 5 case reports in the literature showing HLH in association with PCM. Venizelos et al. ${ }^{[15]}$ reported a 54-year old female with a 6-month history of fever having HLH (fever, pancytopenia, splenomegaly, hemophagocytosis in bone marrow) and kappa light-chain PCM (30\% of plasma cells in bone marrow) co-existing at the time of PCM diagnosis. Our patient also had a 6-month history of fever at the time of HLH diagnosis (pancytopenia, splenomegaly, hemophagocytosis in spleen, high serum ferritin level). At the same period, her pre-existing MGUS progressed rapidly - the emergence of a new serum monoclonal protein, and increased serum free kappa chain and kappa to lambda ratio. Results from repeated bone marrow biopsies ( $<10 \%$ plasma cells in bone marrow) did not meet the diagnostic criteria of PCM. Interestingly, after treatment for HLH, her new serum monoclonal IgG lambda decreased and eventually disappeared upon full recovery. The relationship of the pathogenesis of HLH and the development of a monoclonal gammopathy requires further investigation.

The prognosis of hemophagocytic lymphohistiocytosis is poor with the mortality rate ranging from $22 \%$ to $59 \% .^{[16]}$ Mortality appears to be particularly high among solid organ transplant recipients. In our case, the patient had a very complicated hospital course involving multiple organ systems, including acute kidney failure requiring hemodialysis, respiratory failure, and pulmonary embolism. She eventually recovered and was discharged.

In conclusion, acquired HLH is a life-threatening condition not only associated with hematological malignancies but can also occur in association with a clonal precursor state. To our knowledge, this is the first case report of HLH associated with the development and disappearance of a new monoclonal antibody. Prompt identification (selection of appropriate laboratory tests) and treatment of HLH is critical.

\section{ACKNOWLEDGEMENTS}

We would like to acknowledge the University of Pittsburgh School of Medicine Dean's Faculty Advancement Award funding for Octavia Peck Palmer.

\section{CONFlicts OF InTEREST Disclosure}

No conflicts of interest.

\section{REFERENCES}

[1] Henter JI, Aricò M, Elinder G, et al. Familial hemophagocytic lymphohistiocytosis. Primary hemophagocytic lymphohistiocytosis. Hematol Oncol Clin North Am. 1998; 12: 417-433. PMid:9561910.

[2] Janka G, zur Stadt U. Familial and acquired hemophagocytic lymphohistiocytosis. Hematology Am Soc Hematol Educ Program. 2005: 82-88.

[3] Aricò M1, Boggio E, Cetica V, et al. Variations of the UNC13D gene in patients with autoimmune lymphoproliferative syndrome. PLoS One. 2013; 8: e68045. PMid:23840885. https ://doi .org/10.1 371/journal.pone. 0068045

[4] Boggio E, Aricò M, Melensi M, et al. Mutation of FAS, XIAP, and UNC13D genes in a patient with a complex lymphoproliferative phenotype. Pediatrics. 2013; 132: e1052-1058. PMid:24043286. https://doi.org/10.1542/peds.2012-1838

[5] Janka G, Imashuku S, Elinder G, et al. Infection- and malignancy associated hemophagocytic syndromes. Secondary hemophagocytic lymphohistiocytosis. Hematol Oncol Clin North Am. 1998; 12: 435-444. PMid:9561911. https://doi.org/10.1016/S0889-8 588(05) 70521-9

[6] Hasselblom S, Linde A, Ridell B. Hodgkin's lymphoma, EpsteinBarr virus reactivation, and fatal haemophagocytic syndrome. J Intern Med. 2004; 255: 289-295. PMid:14746567. https ://doi .org/10 $.1046 / j .0954-6820.2003 .01249 . x$

[7] Machaczka M, Vaktnas J. Haemophagocytic syndrome associated with Hodgkin lymphoma and Pneumocystis jiroveci pneumonitis. $\mathrm{Br}$ J Haematol. 2007; 138: 672. PMid:17655724. https://doi .org/ $10.1111 / \mathrm{j} .1365-2141.2007 .06734 . \mathrm{x}$

[8] Janka G. Hemophagocytic lymphohistiocytosis: When the immune system runs amok. Klin Padiatr. 2009; 221: 278285. PMid:19707989. https ://doi .org/10.1055/s-0029-123 7386
[9] Henter JI, Horne A, Aricó M, et al. HLH-2004: Diagnostic and therapeutic guidelines for hemophagocytic lymphohistiocytosis. Pediatr Blood Cancer. 2007; 48: 124-131. PMid:16937360. https: //doi.org/10.1002/pbc.21039

[10] Ishii E, Ohga S, Imashuku S, et al. Nationwide survey of hemophagocytic lymphohistiocytosis in Japan. Int J Hematol. 2007; 86: 58-65. PMid:17675268. https://doi.org/10.1532/IJH97.07012

[11] Anani W, Fox C, Peck Palmer OM. A 72-year old female with markedly elevated ferritin. Clin Chem. 2015; 61: 561-569. PMid:25725050. https://doi.org/10.1373/clinchem. 2014. 231993

[12] Allen CE, Yu X, Kozinetz CA, et al. Highly elevated ferritin levels and the diagnosis of hemophagocytic lymphohistiocytosis. Pediatr Blood Cancer. 2008; 50: 1227-1235. PMid:18085676. https : //doi.org/doi:10.1002/pbc.21423

[13] Henter JI, Samuelsson-Horne A, Aricò M, et al. Treatment of hemophagocytic lymphohistiocytosis with HLH-94 immunochemotherapy and bone marrow transplantation. Blood. 2002; 100: 2367-2373. PMid:12239144. https://doi.org/10.1182/ blood-2002-01-0172

[14] Diaz-Guzman E, Dong B, Hobbs SB, et al. Hemophagocytic lymphohistiocytosis after lung transplant: report of 2 cases and a literature review. Exp Clin Transplant. 2011; 9: 217-22. PMid:21649574.

[15] Venizelos ID, Garipidou V, Perifanis V. Hemophagocytic syndrome associated with multiple myeloma. Leuk Lymphoma. 2002; 43: $897-$ 899. PMid:12153183. https://doi.org/10.1080/1042819029 0017079

[16] Créput C, Galicier L, Buyse S, et al. Understanding organ dysfunction in hemophagocytic lymphohistiocytosis. Intensive Care Med. 2008; 34: 1177-1187. PMid:18427781. https://doi.org/10.1 007/s00134-008-1111-y 